\section{Sistem Penagihan Rekening Air Pelanggan Pada Perusahaan Umum Daerah Air Minum Tirta Pakuan Kota Bogor}

\author{
Adela Putri Humairoh, Sinta Listari dan Rini Syarif \\ Program Studi Perbankan dan Keuangan, Institut Bisnis dan Informatika Kesatuan \\ E - Mail : adela.ph@ibik.ac.id
}

Service Strategy

in Government

Company

\begin{abstract}
Customer Water Account Billing System is a billing activity for water account arrears that implements theapplication system SMS Gateway as a billing effort, where the application can facilitate the billing department in providing information on arrears of bills for customers who have been in arrears for two months and does not apply to customers who are in arrears. for one month for the use of water account services. If there is no payment on customer arrears, then the water line is cut off by PERUMDA Tirta Pakuan Bogor City. The purpose of this final project is to find out the billing system for customer water bills at PERUMDA Tirta Pakuan, Bogor City. To achieve a clear and targeted research target, the authors formulate problems regarding the system applied in the billing of the customer's water account, the stages of billing, the factors that cause arrears in water bills and the obstacles that arise in the billing system and their solutions. Based on the results of the research and discussion, the Customer Water Account Billing System at PERUMDA Tirta Pakuan Bogor City, among others, provides information on water bills for customer arrears. The discussion shows that the company already has a good Billing System, so that all company activities can run effectively and efficiently.
\end{abstract}

Keywords: Billing, Arrears, SMS Gateway

\title{
ABSTRAK
}

Sistem Penagihan Rekening Air Pelanggan merupakan kegiatan penagihan atas tunggakan rekening air yang menerapkan sistem aplikasi SMS Gateway sebagai upaya penagihan, dimana aplikasi tersebut dapat memudahkan bagian penagihan dalam memberikan informasi tunggakan tagihan bagi pelanggan yang telah menunggak selama dua bulan dan tidak berlaku untuk pelanggan yang menunggak selama satu bulan atas pemakaian jasa rekening air. Apabila belum terjadi pelunasan pada tunggakan pelanggan, maka dilakukannya pemutusan saluran air oleh PERUMDA Tirta Pakuan Kota Bogor. Tujuan penelitian Tugas Akhir ini adalah untuk mengetahui sistem penagihan rekening air pelanggan pada PERUMDA Tirta Pakuan Kota Bogor. Untuk mencapai sasaran penelitian yang jelas dan terarah maka penulis merumuskan permasalahan mengenai Sistem yang diterapkan dalam Penagihan Rekening Air Pelanggan, Tahap-tahap Penagihan, Faktor-faktor yang menjadi penyebab atas tunggakan tagihan rekening air serta Kendala yang muncul dalam sistem penagihan dan solusinya. Berdasarkan hasil penelitian dan pembahasan tersebut Sistem Penagihan Rekening Air Pelanggan pada PERUMDA Tirta Pakuan Kota Bogor antara lain memberikan informasi tagihan air atas tunggakan pelanggan. Dalam pembahasan tersebut menunjukkan perusahaan sudah memiliki Sistem Penagihan yang baik, sehingga semua aktivitas perusahaan dapat berjalan secara efektif dan efisien.

Kata Kunci : Penagihan, Tunggakan, SMS Gateway

\section{JABKES}


Service Strategy

in Government

Company

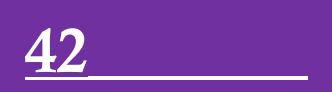

\section{PENDAHULUAN}

Peranan air sangat penting bahkan sudah menjadi bagian dari kehidupan setiap manusia. Air juga merupakan kebutuhan dasar bagi manusia yang senantiasa harus tersedia dalam kehidupan sehari-hari, baik untuk konsumsi, mencuci maupun kebutuhan mandi dan lain sebagainya. Tersedianya air bersih sangat diharapkan masyarakat untuk menunjang aktivitas kehidupan sehari-hari yang tidak dapat terlepas dari kebutuhan air, maka dalam hal ini perlu didukung dengan adanya suatu badan yang profesional dalam mengelola kebutuhan air. Keberadaan Perusahaan Umum Daerah Air Minum Tirta Pakuan Kota Bogor (PERUMDA-TPKB) ini bergerak dalam penyediaan kebutuhan air bersih yang merupakan salah satu Badan Usaha Milik Daerah (BUMD), sehingga perusahaan ini dikenal oleh masyarakat bogor sebagai salah satu sumber dalam pengelolaan serta penyediaan air bersih.

Perusahaan Umum Daerah Air Minum (PERUMDA - TPKB) yang bergerak dibidang jasa pelayanan air, tentunya dalam melayani pelanggan tersebut harus didukung oleh sarana dan prasaran yang memadai dan juga harus didukung oleh kinerja perusahaan dengan sistem yang baik dan teratur. Pelayanan oleh PERUMDA - TPKB kepada pelanggan harus sebaik mungkin, agar pelanggan merasa puas atas pelayanan tersebut, ditambah lagi fasilias yang lengkap, nyaman dan berkualitas bagi pelangganya adalah faktor pendukung dari sebuah pelayanan sehingga tidak terjadi lagi suatu keterlambatan pembayaran air oleh pelanggan, hal tersebut dapat memicu terjadinya tunggakan dalam pembayaran tagihan air. Namun pelanggan yang baik harus selalu memiliki kesadaran atas kewajibannya terhadap pemakaian air dalam memenuhi kebutuhan.

Untuk memenuhi kebutuhan tersebut, perusahaan penyediaan ini harus melakukan kegiatan pelayanan penagihan yang tepat, karena optimal tidaknya pelayanan yang diberikan sangat tergantung dengan cara yang diberikan Perusahaan Umum Daerah Air Minum Tirta Pakuan Bogor dalam kegiatan penagihan.

Menurut Mardi (2011:87) penagihan adalah aktifitas pemrosesan informasi yang mengemas ulang serta meringkas informasi dari entri pemesanan penjualan dan aktifitas pengiriman. Dalam aktifitas penagihan, dokumen dasar yang dibuat adalah faktur penjualan yang menginformasikan kepada pelanggan tentang jumlah kewajiban mereka dari transaksi yang terjadi serta kapan dan dimana mereka akan melunasinya.

Dalam hal lain tagihan disebut juga dengan piutang, yaitu klaim atau pengakuan kepemilikan hak berupa uang, barang, atau jasa oleh seseorang atau suatu perusahaan terhadap pihak lain. Tagihan tidak hanya timbul karena transaksi jual beli baik barang ataupun jasa, tagihan juga bisa timbul karena sebab-sebab lain seperti kewajiban yang dibayar dimuka, hak atau penghasilan yang masih belum diterima, pembayaran uang muka, dan lain-lain

Menurut Jusup (2011:72) " piutang adalah tagihan perusahaan kepada konsumen yang melakukan transaksi secara kredit. Perusahaan biasanya mengharapkan akan dapat menerima kas dari transaksi tersebut dalam waktu 30-60 hari"

Secara menyeluruh penagihan adalah suatu proses kewajiban menagih pelanggan dari transaksi yang telah terjadi sebelumnya sesuai dengan dokumen yang ada, hal tersebut timbul karena adanya penjualan barang atau jasa secara kredit atau disebut dengan piutang atas jasa pemakaian air. Dalam hal itu pihak lain harus melakukan pembayaran tagihan atau pelunasan piutang dalam waktu 30-60 hari atas tunggakan rekening air. Penagihan tersebut ditujukan kepada pelanggan masyarakat Bogor seperti rumah tangga, wirausaha dan perkantoran.

Penagihan pada perusahaan Umum Daerah Air Minum Kota Bogor (PERUMDATPKB) melakukan sistem penagihan melalui aplikasi SMS Gateway, dimana dengan SMS Gateway ini dapat mempermudah bagian penagihan dalam memberikan informasi tunggakan tagihan pelanggan atas pemakaian jasa rekening air. Pelanggan yang hanya menunggak dalam satu bulan berjalan akan dikenakan denda sesuai dengan ketentuan yang berlaku dan tidak dilakukan penagihan melalui SMS Gateway akan tetapi bagi pelanggan yang menuggak dalam dua bulan akan dikirimkan tagihan melalui $S M S$ Gateway yang bertujuan untuk memberikan informasi tagihan dan himbauan kepada 
pelanggan untuk segera melakukan pembayaran agar perusahaan tidak melakukan pemutusan sambungan air oleh pihak Perusahaan Umum Daerah Air Minum Tirta Pakuan Kota Bogor (PERUMDA-TPKB).

Namun disisi lain hal ini dapat memperlambat pendapatan perusahaan karena masih memiliki piutang atas pemakaian jasa rekening air dan tentunya dapat berakibat pada kegiatan operasional perusahaan, maka hal ini dapat memicu kerugian terhadap perusahaan. Dilihat dari pentingnya penagihan bagi perusahaan, membuat perusahaan harus menjalankan suatu sistem penagihan air secara efektif dan efisien bagi Perusahan Umum Daerah Air Minum Tirta Pakuan Kota Bogor (PERUMDA - TPKB).

Berdasarkan hal tersebut, terlihat bahwa tanpa adanya proses penagihan yang baik dapat menyebabkan kerugian yang sebenarnya ingin dihindari. Oleh karena itu, perusahaan ini membutuhkan sistem penagihan yang tersusun rapi dan teratur agar lebih mudah dalam menetapkan tunggakan pembayaran rekening air pelanggan. Dengan adanya penerapan sistem dalam perushaan, diharapkan semua aktivitas dapat berjalan dengan baik dan lancar agar suatu perusahaan dapat mencapai tujuannya.

Berdasarkan identifikasi masalah diatas, maka masalah yang dapat diidentifikasi adalah :

1. Sistem apa yang digunakan dalam proses penagihan pada PERUMDA-TPKB?

2. Bagaimana tahap- tahap penagihan rekening air pelanggan pada PERUMDA-TPKB ?

3. Faktor-faktor apa saya yang menjadi penyebab atas tagihan air yang menunggak pada PERUMDA-TPKB?

4. Apa kendala dan solusi dalam menerapkan sistem penagihan rekening air pelanggan pada PERUMDA-TPKB?

Maksud penulis melakukan peninjauan pada PERUMDA Tirta Pakuan Kota Bogor adalah untuk memperoleh informasi terkait penagihan rekening air. Informasi tersebut digunakan oleh penulis dalam penyusunan Tugas Akhir untuk memenuhi persyaratan kelulusan pada program Vokasional program studi Perbankan \& Keuangan D3 IBI Kesatuan Bogor. Adapun tujuan dari penyusunan Tugas Akhir ini adalah : (1) Untuk mengetahui sistem apa yang digunakan dalam proses penagihan rekening air pada PERUMDA - TPKB. (2) Untuk mengetahui tahap-tahap penagihan rekening air pada PERUMDA - TPKB. (3) Untuk mengetahui faktor-faktor yang menjadi penyebab atas tagihan air yang menunggak pada PERUMDA - TPKB. (4) Untuk mengetahui kendala dan solusi dalam sistem penagihan rekening air pada PERUMDA - TPKB.

\section{HASIL DAN PEMBAHASAN}

Sejarah PERUMDA - TPKB

Kota Bogor yang dahulu dikenal degan nama "BUITENZORG" telah mempunyai sistem pelayanan air minum sejak tahun 1918 yang dibangun oleh Pemerintahan Belanda. Nama perusahaan air minum pada waktu itu adalah "Gemeente Waterleiding Buitenzorg" yang memanfaatkan sumber mata air Kota Batu sebagai sumber air utama yang letaknya di daerah Kabupaten Dati II Bogor dan berjarak $\pm 7 \mathrm{~km}$ dari Kota Bogor dengan kapasitas produksi sebanyak 70 liter per detik. Sumber mata air Kota Batu ini merupakan cikal bakal keberadaan PDAM Kota Bogor sebagai sumber mata air terbaik dan dimulainya pelayanan air minum di kota Bogor. Jumlah penduduk Kota Bogor yang semakin meningkat telah membuat pelayanan air minum di kota hujan ini mengalami perkembangan.

Tahun 1935 Kebutuhan air mengalami peningkatan sebanyak 30 liter per detik yang berasal dari sumber air Kebun Salada milik PAM DKI Jaya dan disebabkan oleh jumlah penduduk di kota Bogor yang semakin meningkat penggunaaan layanan air minum. Pada tahun 1966, jumlah pelanggan tercatat 7000 Sambungan Langganan SL dengan tingkat kehilangan air mencapai 50 persen, dimana persentase kehilangan air tersebut akibat kurang baiknya mutu pipa dinas meter air dan kondisi pipa distribusi yang sudah tua. Saat itulah mulai dirasakan adanya kekurangan air minum. Melihat kondisi tersebut, 
maka dilakukan survei dan perencanaan strategis untuk meningkatkan pelayanan dan pengembangan kapastias jumlah air bersih.

Tahun 1967 untuk menambah kembali kapasitas air, maka sumber air ditambah dengan mengambil dari mata air Bantar Kambing melalui reservoir Cipaku. Namun, rencana ini terhambat masalah pendanaan karena untuk memasang pipa transmisi dibutuhkan dana investasi yang cukup besar. Bantuan dana pun diperoleh dari pemerintah Australia, berupa hibah dengan nama proyek Colombo Plan. Bentuk bantuan yang diperoleh berupa pipa dan aksesorisnya, feasibillity study, perencanaan dan supervise dengan nilai total bantuan sebesar A $\$ 1.736 .000$ atau US $\$ 2.456 .449$. Proyek seluruhnya dilakukan oleh Valentine Lurie and Davies Consulting Engineers dari Sydney, Australia.

Kemudian tahun 1973, dilakukan kembali penambahan kapasitas air melalui sumber mata air Tangkil, Dengan berfungsinya tambahan kapasitas produksi tersebut, maka pada tanggal 3 Juli 1975 dilakukan penghentian atau pemutusan atas koneksi pipa PAM DKI Jaya.

Tahun 1977 PDAM didirikan berdasarkan Peraturan Daerah Kotamadya Daerah Tingkat II Bogor No.5 Tahun 1977 tentang Perusahaan Daerah Air Minum Kotamadya Daerah Tingkat II sebagaimana telah diubah dengan Peraturan Daerah Kotamadya Daerah Tingkat II Bogor No 4 tahun 1990 tentang Perubahan yang Pertama Peraturan Daerah Kotamadya Daerah Tingkat II Bogor No 5 tahun 1977 dan perubahan kedua dengan Peraturan Daerah Kota Bogor No 4 tahun 2004 tentang Perusahaan Daerah Air Mnum Tirta Pakuan Kota Bogor dan terkait dengan Peraturan Daerah Kota Bogor No 4 Tahun 2008 tentang Perusahaan Daerah Air Minum (PDAM) Tirta Pakuan Kota Bogor.

Perusahaan Daerah Air Minum (PDAM) Tirta Pakuan Kota Bogor berubah menjadi Perusahaan Umum Daerah Air Minum Tirta Pakuan Kota Bogor (PERUMDA-TPKB) berdasarkan Peraturan Pemerintah Nomor 54 Tahun 2017 tentang BUMD pada Bab XI evaluasi, restrukturisasi, peubahan bentuk hukum, dan privatisasi BUMD pada bagian ketiga tentang perubahan bentuk hukum BUMD pasal 114 Ayat 3 poin 2 yaitu perubahan bentuk hukum perusahaan perseroan daerah menjadi perusahaan umum daerah.

PERUMDA Tirta Pakuan Kota Bogor yang dahulu bernama PDAM Tirta Pakuan Kota Bogor merupakan perusahaan daerah sebagai sarana penyedia air bersih yang diawasi dan dimonitori oleh aparat - aparat eksekutif maupun legislatif daerah yang berupaya untuk meningkatkan pelayanan kepada masyarakat sesuai dengan misi dan tujuan perusahaan. Salah satunya adalah penerapan manajemen melalui sistem informasi yang ditunjang dengan komputerisasi, jaringan terpadu yang mampu melaksanakan pemantauan di semua bagian dan otomatis semua data administrasi dan penagihan pelanggan secara cepat dan tepat.

\section{Visi Misi Motto Perusahaan Umum Daerah Air Minum Tirta Pakuan Kota Bogor (PERUMDA-TPKB)}

Dalam melaksanakan tugasnya PERUMDA Tirta Pakuan Kota Bogor dilandasi visi dan misi perusahaan.

\section{Visi Perusahaan}

PDAM sehat melalui tata kelola yang baik (Good Corporate Govermance) dalam mewujudkan pelayanan prima kepada pelanggan.

\section{Misi Perusahaan}

1. Menyelenggarakan sistem pelayanan air minum yang unggul berkesinambungan memenuhi mutu yang berlaku untuk menjamin tercapainya kepuasan pelayanan pada pelangan.

2. Mengembangkan bidang usaha sistem pelayanan air minum yang efisien, efektif dan tepat sehingga produk dan kinerja yang dihaslkan dapat dipasarkan dalam jangkauan masyarakat pelanggannya dengan memperhatikan undang-undang perlindungan konsumen.

3. Mewujudkan penyelenggaraan perusahaan milik daerah yang dapat menunjang otonomi daerah secara maksimal. 
4. Menyelesaikan aspek teknik, aspek manajemen dan aspek kewirausahaan dalam penyelenggaraan sistem pelayanan yang berorientasi pada manfaat dan perlindungan sumber daya lingkungan.

5. Mengembangkan penelitian dan kegiatan inovatif serta peningkatan SDM yang dapat menopang tuntutan pertumbuhan kebutuhan perusahaan dan pembangunan nasional pada umumnya.

\section{Tugas Pokok dan Fungsi PERUMDA - TPKB}

PERUMDA Tirta Pakuan Kota Bogor mengutamakan kepuasan pelanggan dengan standar mutu terbaik melalui pelaksanaan moto perusahaan "Handal dalam Pekerjaan, Prima Dalam Playanan". Perumda Tirta Pakuan Kota Bogor diberi wewenang untuk menyelenggarakan pelayanan air minum yang dimanfaatkan untuk masyarakat umum. Untuk melaksanakan kewenangan tersebut, PERUMDA Tirta Pakuan Kota Bogor memiliki ruang lingkup yang terdiri dari tugas pokok dan fungsi.

Adapun Tugas Pokok yang dimiliki oleh PERUMDA Tirta Pakuan Kota Bogor sebagai berikut::

1. Menyediakan pelayanan air minum bagi masyarakat kota Bogor. Penyediaan air minum merupakan salah satu program pemerintah kota Bogor untuk meningkatkan derajat kesehatan bagi masyarakat.

2. Memenuhi kebutuhan air bersih masyarakat kota Bogor secara memadai, adil dan merata

3. Sebagai salah satu sumber Pendapatan Air Daerah (PAD) Pemerintah Kota Bogor

4. Mengatur sistem pendistribusian air minum sesuai dengan kapasitas produksi yang tersedia. Perumda Tirta Pakuan Kota Bogor memiliki tujuan untuk :

a. Memberikan manfaat bagi perkembangan perekonomian daerah

b. Menyelenggarakan Kemanfaatan umum berupa penyedia pelayanan air minum untuk pemenuhan hajat hidup masyarakat dan

c. Memperoleh laba dan/ atau keuntungan.

PERUMDA Tirta Pakuan Kota Bogor mempunyai 2 fungsi sebagai berikut :

1. Fungsi ekonomi, untuk meningkatkan kemampuan pelayanan dan memenuhi kewajiban lainnya dengan cara pengelolaan perusahaan secara sehat berdasarkan asas ekonomi perusahaan.

2. Fungsi sosial, untuk memproduksi air bersih/ air minum yang merupakan kebutuhan pokok manusia senantiasa dituntut untuk dapat memenuhi kebutuhan seluruh lapisan masyarakat dari semua golongan.

\section{Kewajiban PERUMDA - TPKB}

Dalam penyelenggaraan pelayanan air minum, PERUMDA - TPKB mempunyai kewajiban sebagai berikut:

a. Wajib memberikan kegiatan pelayanan air minum.

b. Menyusun, menetapkan, dan mempubliskasikan pedoman pelayanan

c. Mengoperasikan sarana pelayanan ai minum secara optimal.

d. Memberikan pelayanan air minum kepada pelanggan dengan memperhatikan kualitas, kuantitas dan kontinuitas dengan tekanan air minimal 0,5 (nol koma lima) bar atau $5 \mathrm{~m}$ (lima meter) kolom air kecuali dalam keadaan memaksa (force majeure).

e. Memberikan jaminan mutu air minum yang diproduksi dan. Atau pelayanan air minum yang diberikan berdasarkan ketentuan standar mutu air minum dan/ atau kondisi pelayanan air minum yang berlaku.

f. Melaksanakan penggantian meter air akibat rusak, buram, dan lain-lain.

g. Melakukan pemeriksaan kualitas air minum.

h. Memberikan informasi yang benar, jelas dan jujur, mengenai kondisi pelayan air minum dan/ atau kondisi pelayan air minum yang berpotensi akan menyebabkan 
perubahan terhadap kualitas, kuantitas, dan kontinuitas pelayanan, serta memberi penjelasan perbaikan dan pemeliharaannya.

i. Memperlakukan atau melayani pelanggan secara benar dan jujur serta tidak diskriminatif.

j. Melayani dan menindaklanjuti keluhan dan pengaduan pelanggan tentang pelayanan air minum baik secara lisan maupun tertulis.

k. Mengembalikan kelebihan pembayaran (reduksi) dan/atau restitusi akibat kesalahan pembacaan meter air oleh petugas.

1. Memberi kesempatan kepada pelanggan untuk menguji kualitas ai minum, kuantitas, atau keakuratan meter air.

m.Memberi kompensasi, ganti rugi, dan/atau penggantian atas kerugian akibat pelayanan air minum yang tidak sesuai dengan yang dijanjikan PERUMDA-TPKB.

\section{Struktur Organisasi dan Uraian Tugas}

Struktur Organisasi PERUMDA - TPKB

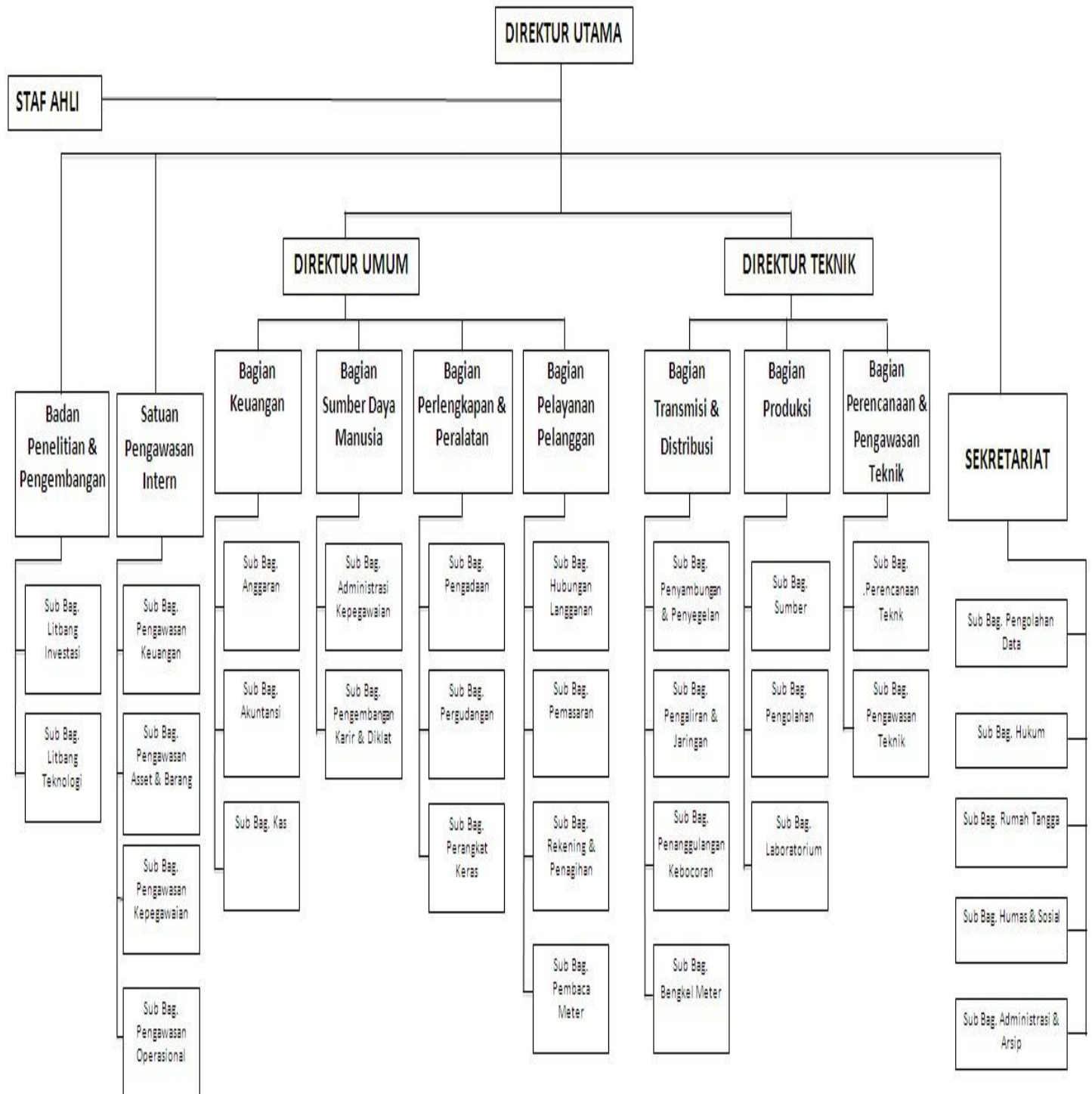

Sumber : Perusahaan Umum Daerah Air Minum Tirta Pakuan Kota Bogor (PERUMDA-TPKB).

Gambar 1. Struktur Organisasi PERUMDA - TPKB 
Struktur organisasi Perusahaan Umum Daerah Air Minum Kota Bogor (PERUMDATPKB) telah ditetapkan berdasarkan Peraturan Wali Kota Bogor Nomor 14 Tahun 2018 tentang Struktur Organisasi dan Tata Kerja perusahaan. Dengan adanya struktur organisasi masing-masing bagian mempunyai tugas, wewenang dan tanggung jawab yang jelas dan tegas dalam menjalankan aktivitas perusahaan, sehingga ada koordinasi yang baik antara atasan dengan bawahan maupun antar kayawan.

Adapun struktur Perusahaan Umum Daerah Air Minum Tirta Pakuan Kota Bogor sesuai dengan surat Walikota Bogor tentang susunan organisasi dan tata kerja perusahaan sehingga struktur organisasi diatas, terdapat pembagian tugas-tugas untuk masing-masing bagian dalam organisasi yaitu sebagai berikut :

1. Direktur Utama

a. Menyusun rencana kerja direktur utama

b. Mendistribusikan dan memberi petunjuk pelaksanaan tugas bawahan

c. Mengevaluasi kinerja karyawan

d. Memotifasi bawahan dalam upaya peningkatan produktifitas kerja dan pengembangan karir

e. Melaksanakan tugas kedinasan lain sesuai perintah atasan

f. Merumuskan strategi perusahaan dan menjalankan kebijaksanaaan yang ditetapkan oleh badan pengawas dalam pelaksanaan operasi perusahaan

g. Memberikan saran dan pertimbangan kepada badan pengawas sebagai bahan pengambilan keputusan

2. Direktur umum

a. Menyusun rencana kerja direktu umum

b. Mengawasi dan menilai diantaranya penutupan asuransi terhadap aktiva

c. Menyempurnakan dan menetapkan rencana konsep naskah dinas, keuangan, pembukuan, pelayanan usaha, umum, kepegawaian SDM sesuai dengan kewenangannya

d. Memberikan saran-saran pertimbangan kepada diektur utama tentang langkahlangkah atau tindakan yang perlu diambil

e. Memelihara hubungan baik dengan bank yang bersangkutan

f. Membuat laporan hasil pelaksanaan tugas kepada atasan

g. Melaksanakan tugas kedinasan lain esuai perintah atasan

3. Direktur Teknik

a. Menyusun rencana kerja direktur teknik

b. Merumuskan perencanaan serta mengendalikan program-program dibagian perencanaan teknik, bagian produksi dan bagian distribusi

c. Merumuskan kebijaksanaan dan mengendalikan proyek-proyek fisik bidang teknik yang ditangani perusahaan

d. Menyusun laporan pelaksanaan tugas dan evaluasi sesuai bidang tugas

e. Melakukan koordinasi dengan direktur administrasi dan keuangan dalam rangka peningkatan pelayanan

f. Melaksanakan tugas lain yang diberikan oleh direktur utama sesuai dibidang tugas

g. Melaksanakan tugas kedinasan lain sesuai perintah atasan

4. Sub Bagian Umum

Bagian rumah tangga

a. Melaksanakan administrasi surat masuk dan keluar

b. Menyiapkan sarana dan prasarana rapat atau pertemuan

c. Menyusun dan melaksanakan tata naskah dinas dan kearsipan dilingkungan perusahaan

Bagian hukum dan kepegawaian

a. Menyusun produk-produk hukum yang diperlukan perusahaan

b. Menyelenggarakan administrasi kepegawaian yang meliputi penyusunan mutasi formasi dan penerapan disipkin karyawan

c. Merencanakan dan melaksanakan program pemberdayaan karyawan 
Bagian pengadaan dan pemeliharaan

a. Menyiapkan daftar harga perkiraan sendiri

b. Melakukan pemeliharaan bangunan dan prasarana kantor

c. Menyediakan sarana dan prasarana perusahaan

Bagian gudang

a. Melaksanakan penyimpanan dan pendistribusian perbekalan dan perlengkapan

b. Mengendalikan stok barang agar sesuai dengan stok minimum dan maksimum

c. Menyelenggarakan administrasi pergudangan sesuai dengan ketentuan yang berlaku

5. Sub Bagian Keuangan

Bagian analisa keuangan

a. Menyusun rencana anggaran dan pendapatan belanja perusahaan

b. Melakukan verifikasi permintaan penggnaan anggaran

c. Melakukan evaluasi terhadap realisasi penggunaan anggaran

Bagian akuntansi

a. Membukukan, meneliti, dan mencocokan semua transaksi keuangan sesuai dengan ketentuan yang berlaku

b. Menyiapkan dan menyusun laporan keuangan, baik laporan bulanan maupun tahunan

Bagian pengendali rekening

a. Menyelenggarakan administrasi pembayaran oleh pelanggan

b. Melaksanakan penagihan piutang kepada pelanggan

c. Menyusun daftar pelanggan yang terlambat membayar rekening

Bagian pembedaharaan

a. Menyusun laporan kas baik harian maupun bulanan

b. Menyelenggarakan pengelolaan kas kecil

c. Melaksanakan pembuatan gaji dan pembayaran gaji karyawan

6. Sub Bagian Langganan

Bagian pelayanan dan pemasaran

a. Menerima dan mencatat pengaduan dari pelanggan

b. Melaksanakan pemantauan dan evaluasi tugas pelayanan

c. Menerima permohonan pelanggan beru, penggantian meter dan balik nama

Bagian pembaca meter

a. Melakukan pembacaan dan pencatatan stand meter pelanggan

b. Melakukan penelitian dan pengecekan di lapangan untuk memastikan kebenaran pembaca meter

c. Menyerahkan laporan hasil pembacaan dan pencatatan stand meter kepada sub bagian pengolah rekening

Bagian pengolah rekening

a. Melakukan kegiatan pembuatan rekening berdasarkan pembacaan stand meter

b. Melakukan pengecekan terhadap rekening yang dianggap tidak sesuai dengan pemakaian untuk dikoordinasikan dengan sub bagian pembaca meter

7. Sub Bagian Litbang

Bagian umum dan teknik

a. Melaksanakan penelitian, evaluasi sistem dan prosedur operasional perusahaan

b. Menyusun program pengembangan perusahaan jangka menengah dan panjang

c. Melaksanakan evaluasi pengembangan perusahaan

8. Sub Bagian SPI

Bagian umum dan teknik

a. Melaksanakan pengawasan dan pengendalian intern perusahaan

b. Melaksanakan pengawasan terhadap penyelenggaraan tata krja sesuai ketentuan yang berlaku

c. Melaksanakan pengawasan dan pemeriksaan atas pengelolan keuangan, materil dan personal 
9. Sub Bagian perencanaan dan pengawasan teknik

Bagian perencanaan teknik

a. Mengumpulkan data-data teknin sebagai bahan perencanaan pengembangan dan rehabilitas sistem penyedia air bersih

b. Melakukan survey harga pasar sebagai bahan penyusunan rencana anggaran biaya

c. Melakukan survey lapangan dan menyimpan arsip serta dokumen perencanaan

Bagian pengawasan teknik

a. Menerima permohonan pemasangan sambungan pelanggan dari bagian langganan

b. Melakukan peninjauan lapangan guna perencanaan penyambungan dan rehabilitas sambungan pelanggan

c. Menyusun daftar kebutuhan peralatan yang digunakan untuk penyambungan

10. Sub Bagian produksi

Bagian sumber

a. Mengendalikan operasional pompa-pompa produksi guna tercapainya kebutuhan suplay air bersih

b. Melakukan pemeliharaan mesin-mesin produksi dan fasilitas pengolahan

c. Membuat laporan harian dan bulanan tentang produksi air, operasional pompa, pemakaian listrik, dan tekanan produksi lain yang dianggap perlu

Bagian laboratorium

a. Melakukan pemeriksaan kualitas air baik di sumber, distribusi maupun pelanggan

b. Melakukan analisa kualitas air dan kebutuhan bahan kimia untuk direkomendasikan kepada sub bagian sumber dan perpompaan untuk menjamin kualitas air sesuai ketentuan yang berlaku

c. Memelihara dan mengamankan bahan kimia dan peralatan laboratorium

11. Sub Bagian dan distribusi

Bagian penyambunan dan pemasangan

a. Melaksanakan pemasangan jaringan pipa distribusi sesuai program perusahaan

b. Melaksanakan perbaikan dan pemeliharaan jaringan pipa distribusi termasuk pengurasan pipa

c. Melakukan pemantauan jaringan dalam upaya menurunkan tingkat kehilangan air

Bagian pengaliran dan pemeliharaan jaringan

a. Melakukan pengecekan, penggantian, dan penyegelan instalasi meter pelanggan

b. Melaksanakan pemeliharaan dan perbaikan instalasi sambungan pelanggan

c. Melaksanakan pemutusan dan penyambungan kembali instalasi sambungan pelanggan sesuai surat perintah

Bagian bengkel meter

a. Menerima permohonan perbaikan mesin-mesin dan peralatan dari bagian lain termasuk meter air

b. Memelihara dan mengamankan peralatan bengkel

\section{Sumber Daya Manusia}

Setiap perusahaan selalu membutuhkan faktor tenaga kerja manusia, dalam hal ini adalah karyawan. Peran serta karyawan dalam melaksanakan tugasnya sangat mendukung suatu pencapaian tujuan perusahaan. Sumber daya manusia adalah langkah strategis yang dilakukan Perusahaan Umum Daerah Air Minum Tirta Pakuan Kota Bogor untuk pencapaian target bisnis perusahaan sehingga dierlukan serangkaian upaya yang terarah guna mengembangkan sumber daya manusia. Dengan kegiatan Manajemen Sumber Daya Manusia yang baik, maka akan dihasilkan SDM berkualitas yang dapan menunjang visi dan misi perusahaan. Pengembangan sumber daya manusia yang tiada henti, sehingga manajemen dilakukan dan didukung oleh sumber daya yang profesional. Melakukan efisiensi yang terarah dalam pengelolaan sumber dana yang baik terhadap 
perusahaan serta menerapkan teknologi informasi yang tepat agar perusahaan dapat mengikuti teknologi masa kini yang sangat berguna. Untuk terciptanya keberhasilan kerja pada unit aministrasi dan arisp maka jumlah karyawan pada unit administrasi dan arsip yang terdapat di Perusahaan Umum Daerah Air Minum Kota Bogor (PERUMDATPKB) adalah 19 orang terdiri dari 1 General Manager, 8 orang Asmen (Asisten Manager), 10 orang Staff admin.

Adapun jumlah karyawan pada unit Administrasi dan Arsip sebagai berikut :

Tabel 1. Tabel jumlah karyawan unit Administrasi dan Arsip

\begin{tabular}{|c|c|c|c|}
\hline No & Jabatan & Tingkat Pendidikan & Jumlah Orang \\
\hline 1 & Manager & S2 & 1 \\
\hline 2 & Asmen & S1 & 3 \\
\hline 3 & Asmen & D3 & 5 \\
\hline 4 & Staf & S1 & 3 \\
\hline 5 & Staf & D3 & 2 \\
\hline 6 & Staf & SMA & 2 \\
\hline
\end{tabular}

Sumber Data : Perusahaan Umum Daerah Air Minum Tirta Pakuan Kota Bogor (PERUMDA-TPKB) 2020

\section{Sarana dan Prasarana}

Sarana dan prasarana merupakan peralatan dan perlengkapan yang digunakan untuk membantu setiap pelaksanaan kerja karyawan kantor yang berguna untuk memudahkan suatu pekerjaan sehingga menjadi lebih cepat, tepat, dan baik.

Sarana dan prasarana yang tersedia yang dapat menunjang kegiatan di bagian unit Administrasi dan Arsip adalah :

1. Telepon

Alat ini digunakan untuk memudahkan unit lain untuk menghubungi karyawan dalam menanyakan beberapa surat masuk ataupun menyampaikan pesan pekerjaan yang terdapat dibagian unit lainnya. Pada unit Administrasi dan Arsip terdapat dua telepon dalam satu ruangan, yaitu ruangan Sekper (Sekertaris Perusahaan) dan ruangan karyawan.

2. Komputer

Komputer merupakan alat yang digunakan untuk membuat surat masuk dan surat keluar, menginput surat masuk dan surat keluar, membuat tanda terima surat keluar, membuat label surat, mengarsip surat masuk dan surat keluar, menyimpan data-data penting, serta mengirimkan file atau menerima file dari bagian unit lainnya maupun dari pihak luar perusahaan. Unit Administrasi dan Arsip menyediakan tiga komputer untuk karyawannya.

3. Printer

Printer digunakan biasanya untuk mencetak dokumen yang akan digunakan seperti tanda terima surat, kop surat, surat keluar, surat tugas dan surat perjalanan dinas. Unit Administrasi dan Arsip menyediakan satu printer.

4. Faxmail

Faxmail digunakan untuk mengirim tagihan rekening air minum kepada perusahaan dan menerima surat undangan melalui fax dari pemerintahan setempat. Terdapat satu faxmail pada Unit Administrasi dan Arsip.

5. Scanner

Scanner digunakan untuk menduplikat surat dan surat yang telah discan kemudian dikirimkan ke komputer dalam bentuk digital. Unit administrasi menyediakan satu scanner.

6. Mesin Fotocopy

Mesin fotocopy digunakan untuk menggandakan surat atau untuk keperluan pekerjaan, biasanya bagian yang disekitar ruang lingkup Adm dan Arsip yang beada di lantai 2 bisa menggunakan mesin tersebut kecuali pada berkas atau dokumen 
dengan lembar atau halaman yang berjumlah banyak, bisa menggunakan jasa fotocopyan yang berada pada lantai 1 . Terdapat satu mesin fotocopy pada unit Administrasi dan Arsip

7. ATK ( Alat Tulis Kantor)

Alat tulis kantor ini digunakan untuk memudahkan karyawan dalam menyelesaikan suatu pekerjaannya seperti pulpen, pensil, penghapus, tipex, spidol, penggaris, staples, gunting, cutter, stempel, buku quarto, box file, kertas HVS, lakban bening atau coklat, lem stik, tinta dan pita printer, kop surat perusahaan, amplop serta map.

8. Pendingin Ruangan (AC)

Alat ini berfungsi memberikan suasana dan hawa sejuk diruangan kerja karyawan. Unit Aministrasi dan Arsip memiliki dua pendingin ruangan (AC)

9. Meja

Benda ini berfungsi untuk menyimpan semua perlengkapan kerja yang akan dipergunakan oleh karyawan untuk membantu pelaksanaan tugas kerja seperti komputer, printer, scanner, faksimile, telpon, atau berkas-berkas lainnya lainnya. Terdapat lebih dari dua meja yang dimiliki unit Administrasi dan Arsip.

10. Kursi

Benda ini berfungsi untuk memberikan kesan nyaman kepada para karyawan untuk duduk dalam melayani tamu yang memiliki kepentingan. Terdapat lebih dari dua kursi yang dimiliki unit Administrasi dan Arsip.

11. Sofa

Benda ini disediakan untuk para tamu yang memiliki kepentingan dengan sekertaris perusahaan pada bagian unit administrasi dan arsip. Unit Administrasi dan Arsip mempunyai satu sofa yang tersedia di ruangan Sekper (Sekertaris Perusahaan).

12. Lemari

Lemari ini berfungsi untuk menyimpan alat-alat kerja para pegawai seperti berkasberka arsip surat masuk dan surat keluar agar tertata rapih serta untuk menyimpan ATK , buku catatan, amplop dan map. Terdapat empat lemari yang dimiliki unit Administrasi dan Arsip.

13. Kulkas

Kulkas digunakan untuk menaruh makanan dan minuman para karyawan agar tetap tahan lama dan terlihat rapih. Terdapat satu kulkas pada unit Administrasi dan Arsip.

14. Lukisan

Interior kantor ini digunakan untuk menambah suasana menjadi menyenangkan sehingga memberi semangat dan kenyamanan kepada karyawan maupun kepada tamu yang datang. Terdapat dua lukisan pada unit Administrasi dan Arsip.

15. Tempat Sampah

Tempat sampah disediakan untuk membuat ruangan tetap bersih dari sisa makanan ataupun dari berkas-berkas sisa pekerjaan. Tempat sampah disediakan sesuai jenis sampahnya, ada tempat sampah organik dan tempat non organik, tempat sampah kertas dan plastik. Pada unit Administrasi dan Arsip menyediakan dua tempat sampah.

\section{Uraian singkat Magang}

Penulis melaksanakan kegiatan magang yang dilakukan di PERUMDA-TPKB dan ditempatkan di bagian Administrasi dan Arsip, waktu pelaksanaan dimulai pada tanggal 3 Februari 2020 - 13 Maret 2020. Dalam kegiatan magang harian, jam kerja ditentukan oleh pihak PERUMDA-TPKB yakni dimulai pada pukul 07.30 sampai 16.30 WIB setiap hari Senin - Jumat dan waktu istirahat pukul 12.00 sampai dengan pukul 13.00 WIB .

Dalam kegiatan magang pada Perusahaan Umum Daerah Air Minum Tirta Pakuan Kota Bogor, teori - teori yang diberikan dan berkaitan dengan pembelajaran yang diajarkan pada waktu magang, antara lainya yaitu : 
1. Mencatan Surat masuk

Mencatat surat masuk adalah mencatat kembali surat ke dalam buku besar, biasanya dalam mencatat surat masuk harus melampirkan kertas disposisi. Disposisi adalah selembar kertas untuk ditempelkan pada surat masuk sebagai bukti ditujukan untuk siapa surat masuk tersebut. Disposisi tersebut dibagi menjadi dua yaitu disposisi untuk Sekper (sekertaris perusahaan) dan disposisi untuk Dirut ( Direktur Utama). Surat yang ditujukan kepada Sekper berupa proposal permohonan dana atau surat yang berasal dari internal (Dalam Lingkup Perusahaan) sedangkan surat yang ditujukan kepada Dirut berupa surat undangan atau surat-surat lainnya.

2. Membuat Surat Keluar

Membuat surat keluar adalah mencatat surat keluar ke dalam buku besar yang sudah disediakan, biasanya surat yang dibuat dan dicatat yaitu seperti surat atas kerjasama suatu perusahaan, surat undangan, surat pemberitahuan biaya, surat balasan keluhan pelanggan.

3. Menginput Data Surat Keluar

Menginput datat surat keluar adalah menginput data sesuai dengan yang sudah dicatat ke dalam buku besar, biasanya surat keluar yang baru akan dicatat kedalam buku besar yang nantinya dapat memudahkan dalam proses input data dan sebagai arsip surat keluar. Sehingga apabila nantinya terjadi kendala maka bisa dicek menyesuaikan apa yang dicatat kedalam buku besar dengan data yang di input.

4. Menerima telepon

Menerima telepon adalah hal dimana beberapa bagian lainnya ingin menanyakan suatu surat dari pihak lain kepada Adm dan Arsip. Surat yang sering ditanyakan pada bagian lain biasanya ada pada proposal atau undangan, kemudian bagian tersebut menanyakan tentang disposisi atau dibagian mana surat tersebut disimpan. Disposisi yang dimaksud disini adalah suatu selembar kertas yang berisi balasan dari Sekper (Sekertaris Perusahaan) atau Dirut (Dirktur Utama) tergantung jenis suratnya, bagian Adm dan Arsip bertugas mencari surat yang diperlukan. Untuk memudahkan bagian Adm dan Arsip dalam mencari surat, maka hal pertama yang ditanyakan kepada bagian terkait yaitu mengenai dari siapa surat tersebut dan tanggal berapa surat tersebut masuk. Sehingga bagian Adm dan Arsip dapat mudah menemukan surat yang ditanyakan melalui sambungan telepon.

5. Menggandakan Surat

Menggandakan surat adalah memperbanyak surat masuk yang nantinya akan di berikan kepada unit lain, tergantung seberapa banyak surat yang diperintahkan untuk bagian unit lain yang harus diberikan. Surat tersebut sesuai dengan kertas disposisi Sekper (Sekertaris Perusahaan) atau kertas disposisi Dirut (Direktur Utama).

6. Mengantarkan berkas

Mengantar berkas adalah kegiatan memberikan berkas kepada bagian unit yang sudah dicatat dan digandakan sesuai dengan perintah yang ada pada kertas disposisi Sekper (Sekertaris Perusahaan) dan kertas disposisi Dirut (Direktur Utama) biasanya berkas yang dibagikan seperti surat masuk undangan dan proposal permohonan bantuan dana. Setelah bagian unit menerima berkas tersebut makan unit terkait wajib memberikan tanda tangan sebagai tanda bukti bahwa surat tersebut telah diberikan kepada yang bersagkutan.

7. Menstempelkan surat

Menstempelkan surat adalah menempelkan cap memakai stempel diatas keterangan nama direktur utama dan dibawah keterangan tempat dan tanggal, biasanya posisi untuk menempelkan stempel pada surat berada dibawah kanan yang tertera pada surat keluar.

8. Membuat tanda terima surat

Membuat tanda terima surat adalah membuat tanda terima yang berisi tentang Nomor surat, untuk siapa surat itu diberikan dan berisi keterangan atau perihal yang berkaitan dengan surat tersebut. 
9. Membuat label

Membuat label adalah menginput data label yang berisi untuk siapa surat tersebut diberikan dan alamat pihak terkait atas surat tersebut. Dalam membuat label surat keluar ini biasanya melihat buku besar surat keluar atau melihat dari surat keluar yang akan diberikan kepada yang ditujukan. Setelah label sudah dibuat dan dicetak, nantinya label surat ini ditempelkan didepan amplop PERUMDA-TPKB.

10. Melipatkan surat

Melipatkan surat adalah kegiatan melipat suatu surat menjadi empat atau tiga lipatan tergantung pada jenis kertas surat keluart, jika surat tersebut menggunakan jenis kertas A4 maka surat tersebut dilipat menjadi tiga bagian tetapi jika surat terserbut menggunakan kertas F4 maka bisa dilipat menjadi empat bagian, sehingga lebih mudah dimasukkan kedalam amplop dan terlihat lebih rapih.

11. Memasukkan surat ke Amplop

Memasukkan surat ke amplop adalah kegiatan memasukan surat yang sudah dilipat rapih terlebih dahulu untuk dikirim kepada pihak terkait. Setelah surat sudah dimasukkan kedalam amplop dan sudah rapih kemudian di bagian depan amplop tersebut ditempelkan tanda bukti surat yang bertujuan untuk memudahkan pihak pengirim.

\section{Hasil Pembahasan dari Identifikasi Masalah \\ Sistem yang digunakan dalam proses penagihan pada PERUMDA-TPKB}

PERUMDA Tirta Pakuan Kota Bogor berperan dalam melakukan penagihan kepada pelanggan aktif yang merupakan suatu dinamika dalam menjalankan proses bisnis perusahaan, dimana pola pelanggan yang melakukan pembayaran rekening air tidak selalu sama. Faktor ekonomi merupakan salah satu faktor utama penyebab terlambatnya pelanggan dalam melakukan pembayaran rekening air, hal itu berdampak pada siklus bisnis perusahaan karena semakin banyak pelanggan yang menunggak maka akan semakin besar pengaruhnya terhadap cash flow perusahaan serta tingginya piutang usaha yang dapat mengakibatkan terganggunya operasional perusahaan akibat banyaknya tunggakan rekening air.

Penerapan denda keterlambatan bagi pelanggan dapat membentuk pola pembayaran pelanggan. Klasifikasi denda keterlambatan dihitung berdasarkan tanggal pembayaran, semakin lama pelanggan membayar semakin besar tarif denda keterlambatan yang dikenakan. Pelanggan dengan tunggakan bulan pertama dihitung dari tanggal 21-30 bulan berjalan hingga 1 bulan dan di bulan berikutnya pelanggan dengan tunggakan bulan kedua dikategorikan pelanggan menunggak selama 2 bulan.

Pelanggan yang menunggak setiap bulannya berdampak terhadap pendapatan perusahaan. Untuk mengantisipasi akumulasi tunggakan yang semakin besar setiap bulannya perusahaan memberlakukan denda keterlambatan yang lebih besar bagi pelanggan yang menunggak hingga bulan berikutnya diatas 1 bulan dan diberlakukan penagihan tunggakan melalui sistem aplikasi SMS Gateway.

Sistem aplikasi SMS Gateway ini merupakan suatu aplikasi yang berada didalam sistem aplikasi pelanggan yang digunakan oleh perusahaan dalam melakukan penagihan piutang rekening air bagi pelanggan yang mulai menunggak selama 2 bulan. Informasi tunggakan pelanggan yang dikirim melalui aplikasi SMS Gateway berkaitan tentang tagihan rekening air, denda keterlambatan serta himbauan untuk segera melakukan pembayaran sebelum dilakukannya pencabutan sambungan air dibulan ke 3 oleh petugas yang diinformasikan kepada pelanggan. Dalam perkembangannya sistem aplikasi ini tentunya dapat memudahkan pelanggan dan perusahaan dalam melakukan penagihan.

\section{Tahap- Tahap Penagihan Rekening Air}

PERUMDA Tirta Pakuan Bogor memiliki sistem penagihan melalui aplikasi SMS Gateway, dalam sistem ini dapat mempermudah bagian penagihan maupun para 
pelanggan. Untuk hal ini terdapat beberapa tahapan dalam persiapan dan pelaksanaan penagihan dalam menggunakan sistem aplikasi SMS Gateway sebagi berikut :

1. Bagian penagihan melakukan input akses terhadap sistem informasi pelanggan.

2. Bagian penagihan melakukan Query (pemilihan data) bagi pelanggan dengan tunggakan 2 bulan melalui sistem informasi pelanggan.

3. Setelah pemilihan data selesai kemudian diklasifikasikan berdasarkan jumlah pelanggan yang harus diinformasikan melalui aplikasi SMS Gateway.

4. Data hasil rekapan pelanggan diinput ke dalam sistem.

5. Input data dilakukan secara bertahap berdasarkan data yang diklasifikasikan.

6. Kemudian dilakukan pengiriman tagihan melalui aplikasi SMS Gateway

7. Hasil dari SMS Gateway tersebut dibuat laporan berapa pelanggan yang dikirimkan melalui aplikasi tersebut.

PERUMDA Tirta Pakuan Kota Bogor juga sudah mempunyai tahap-tahap dalam mengantisipasi kecendrungan bagi pelanggan yang menunggak rekening air sebagai antisipasi meningkatnya piutang usaha atas pemakaian jasa air. Tahap-tahap penagihan oleh PERUMDA Tirta Pakuan Kota Bogor sebagai berikut :

a. Bagian penagihan setiap tanggal 21 dibulan berjalan hingga akhir bulan melakukan pengecekan atas pemeriksaan terhadap pembayaran rekening air pelanggan melalui aplikasi sistem informasi pelanggan, sebagai bentuk antisipasi terhadap tunggakan pelanggan

b. Setelah melakukan pemeriksaan oleh bagian penagihan kemudian dikirimkan pemberitahuan kepada pelanggan yang menunggak 2 bulan mengenai hal tagihan rekening air melalui aplikasi SMS Gateway dan tidak berlaku bagi pelanggan yang hanya menunggak selama satu bulan, bagi pelanggan tersebut akan dikenakan denda administrasi .

c. Setelah pemberitahuan tagihan air yang diberikan perusahaan kepada pelanggan maka data pelanggan tersebut secara otomatis dalam sistem informasi pelanggan masuk dalam pemantauan petugas pencabutan.

d. Bagi pelanggan yang memiliki tunggakan 3 bulan, namun pelanggan tidak melakukan pembayaran terhadap tunggakan tersebut, maka dibuatlah surat pemutusan yang langsung diantar ke rumah pelanggan.

e. Dalam masa pemutusan, pelanggan diberikan waktu selama 3 bulan untuk melunasi tagihan rekening air dan mengurus pencabutan meter air. Setelah 3 bulan, pelanggan diharuskan mengurus pemasangan baru kembali dengan biaya normal yang berlaku.

f. Pelanggan yang diputus meter air bisa mencicil pembayaran tagihan sebanyak 5 kali hingga 10 kali dengan mengajukan surat permohonan cicilan pemasangan kembali kepada perusahaan.

Dalam penagihan rekening air terdapat keterangan sanksi administrasi atau denda bagi pelanggan yang menunggak pembayaran tagihan rekening air atas pemakaian jasa air yang telah digunakan. 
Adapun Sanksi Administrasi pada unit Penagihan sebagai berikut :

Tabel 2. Tabel sanksi Aministrasi pada unit Penagihan

\begin{tabular}{|l|l|l|}
\hline \multicolumn{2}{|c|}{ Rekening Berjalan } & \multicolumn{1}{c|}{ Denda } \\
\hline \multirow{4}{*}{$\begin{array}{l}\text { Mulai Tg1 21 - 31 untuk } \\
\text { tunggakan bulan pertama }\end{array}$} & $\begin{array}{l}\text { Rekening } \leq \text { Rp. 50.000,- } \\
\text { (Lima Puluh Ribu } \\
\text { Rupiah) }\end{array}$ & $\begin{array}{l}\text { Rp. 7.500,- } \\
\text { (Tujuh Ribu Lima Ratus } \\
\text { Rupiah) }\end{array}$ \\
\cline { 2 - 3 } & $\begin{array}{l}\text { Rekening > Rp. 50.000,- } \\
\text { (Lima Puluh Ribu } \\
\text { Rupiah) }\end{array}$ & $\begin{array}{l}\text { 15\% (Lima Belas Persen), } \\
\text { dari rekeing air minum }\end{array}$ \\
\hline $\begin{array}{l}\text { Mulai Tgl. 1 - Bulan } \\
\text { berikutnya dan seterusnya }\end{array}$ & $\begin{array}{l}\text { Rekening } \leq \text { Rp. 50.000,- } \\
\text { (Lima Puluh Ribu } \\
\text { Rupiah) }\end{array}$ & $\begin{array}{l}\text { Rp. 10.000,- } \\
\text { (Sepuluh Ribu Rupiah) }\end{array}$ \\
\cline { 2 - 3 } & $\begin{array}{l}\text { Rekening > Rp. 50.000,- } \\
\text { (Lima Puluh Ribu }\end{array}$ & $\begin{array}{l}\text { 20\% (Dua Puluh Persen), } \\
\text { dari rekening air minum }\end{array}$ \\
\hline
\end{tabular}

Sumber Data : Perusahaan Umum Daerah Air Minum Tirta Pakuan Kota Bogor (PERUDA-TPKB) 2020

\section{Ketentuan Penagihan}

Untuk mendukung berjalannya kegiatan penagihan tentunya PERUMDA Tirta Pakuan Kota Bogor membuat suatu ketentuan dalam penagihan rekening air , sebelum proses tahap penagihan dilakukan, bagian penagihan harus mengetahui ketentuan yang telah dibuat oleh perusahaan mengenai tagihan rekening air. Ketentuannya yang perlu diperhatikan antara lain seperti :

1. Rekening tunggakan harus dilunasi terlebih dahulu sebelum rekening

2. bulan berjalan dibayarkan.

3. Rekening berdasarkan pemakaian bulan lalu (1 bulan).

4. Pembayaran rekening air minum mulai tanggal $1 \mathrm{~s} / \mathrm{d} 20$ setiap bulan di unit-unit pelayanan Wilayah PERUMDA Tirta Pakuan Kota Bogor.

5. Pembayaran diatas tanggal 20 akan dikenakan denda keterlambatan sesuai ketentuan berlaku.

6. Apabila sampai dengan akhir bulan berjalan rekening air belum terbayar, maka terhitung mulai tanggal 1 bulan berikutnya dikenakan denda keterlambatan yang lebih besar.

7. Jika dalam waktu 2 bulan pelanggan belum melunasi pembayaran rekening air, maka PERUMDA Tirta Pakuan Kota Bogor akan melakukan pemberitahuan melalui aplikasi SMS Gateway.

8. Apabila ternyata dalam waktu 3 bulan pelanggan belum melunasi pembayaran rekening air, maka PERUMDA Tirta Pakuan Kota Bogor akan melakukan pemutusan sambungan air.

9. Pelanggan diberikan batas waktu selama 3 bulan untuk melunasi tagihan rekening air.

10. Kemudian selama 3 bulan setelah pemutusan pelanggan belum melunasi, maka ditetapkan sebagai ex-pelanggan yang dikategorikan sudah bukan pelanggan.

\section{Faktor-faktor terjadinya tunggakan rekening air}

Tagihan rekening air yang menunggak disebut juga sebagai piutang. Piutang yang tidak tertagih berpotensi hilangnya pendapatan penjualan air pada Perusahaan Umum Daerah Air Minum Tirta Pakuan Kota Bogor (PERUMDA-TPKB). Piutang itu sendiri timbul akibat pelanggan tidak menjalankan kewajiban atas penggunaan jasa saluran air yang dihitung dari pemakaian berdasarkan meter kubik yang digunakan dan ditetapkan berdasarkan tarif yang berlaku. 
Adapun faktor-faktor terjadinya tunggakan pembayaran oleh pelanggan atas penagihan yang menyebabkan terjadinya piutang usaha oleh perusahaan diantaranya adalah sebagai berikut :

a. Adanya wabah penyakit yang berdampak terhadap stabilitas ekonomi.

b. Adanya tahun ajaran baru sekolah yang menyebabkan pelanggan lebih mendahulukan membayar keperluan sekolah dan menunda pembayaran rekening airnya yang menimbulkan tunggakan rekening.

c. Adanya hari-hari besar seperti lebaran yang menyebabkan keperluan keluarga sangat meningkat sehingga pelaggan memiliki kecenderungan untuk menunda pembayaran rekening airnya.

d. Adanya sumber piutang tak tertagih karena pelanggannya lari, meninggal, bangkrut, sehingga tidak mampu untuk membayar lagi.

e. Adapun piutang tak tertagih yang timbul karena pelanggan pertama (pemilik rumah) tidak membayar tunggakan rekening air sehingga terbebankan ke pelanggan kedua (penyewa).

\section{Kendala dan solusi dalam menerapkan sistem penagihan rekening air pelanggan Kendala Sistem penagihan rekening air}

Adapun kendala dalam menerapkan sistem penagihan rekening air pada PERUMDATPKB dapat dijelaskan sebagai berikut :

1. Sulitnya penagihan bagi pelanggan yang sudah dicabut atau sudah menjadi expelanggan dalam melakukan penagihan.

2. Sulitnya penagihan karena pelanggan tersebut memiliki hubungan dengan perusahaan PERUMDA, sehingga jika dilakukan eksekusi akan timbul conflict of interst.

\section{Solusi yang dilakukan dalam mengatasi kendala sistem penagihan rekening air} Adapun solusi terhadap kendala yang terjadi dalam menerapkan sistem penagihan rekening air pada PERUMDA-TPKB dapat dijelaskan sebagai berikut :

1. Perusahaan bekerjasama dengan institut resmi seperti kantor kejaksaan dalam hal melakukan penagihan tunggakan rekening air ex-pelanggan yang sudah diakui sebagai piutang ragu-ragu/ piutang tak tertagih untuk melakukan eksekusi pada pelanggan tersebut dengan cara melakukan pemanggilan dengan menyampaikan surat kepada expelanggan terlebih dahulu pada PERUMDA jika sudah melakukan pembayaran maka telah selesai permasalahannya jika belum melakukan pembayaran maka akan ditindaklanjuti dengan surat pemanggilan kedua yang dikeluarkan oleh kejaksaan.

2. Bagi pelanggan yang memiliki conflict of interest dengan perusahaan maka direksi dapat memberikan keringanan berupa penghapusan denda atau pemberian diskon kepada pelanggan.

\section{PENUTUP}

Berdasarkan hasil pembahasan pada Bab III mengenai sistem penagihan rekening air pelanggan pada PERUMDA Tirta Pakuan Kota Bogor dapat disimpulkan sebagai berikut

1. Penagihan yang dilakukan pada Perumda menggunakan sistem penagihan melalui SMS Gateway untuk memberikan informasi mengenai tunggakan tagihan pelanggan bagi pelanggan yang menunggak diatas satu bulan atau mulai masuk dalam dua bulan tunggakan.

2. Dengan adanya tahapan penagihan rekening air yang dilakukan oleh Perumda diharapkan dapat membantu penagihan, sehingga penagihan menjadi lebih terarah

3. Berdasarkan penagihan rekening air Perumda memiliki faktor-faktor yang menyebabkan terjadinya piutang usaha atas tunggakan pembayaran air oleh pelanggan.

4. Perumda masih mengalami beberapa hambatan utamanya dalam hal penagihan 


\section{DAFTAR PUSTAKA}

Efendi. Jonaedi. 2016. Kamus Istilah Hukum Populer. Jakarta : Prenada Media Group. Firmansyah, M. Anang. 2019. Perilaku Konsumen. Yogyakarta : Qiara Media Hutahaean, Jeperson. 2015. Konsep Sistem Informasi. Yogyakarta : Deepublish. Irma, Ramadhani. 2017. Akutansi Dasar. Sidoarjo : Uwais Inspirasi Indonesia Rochmah, Siti. 2013. Kebijakan Pelayanan Studi Kebijakan Pelayanan Air Bersih. Malang : Universitas Brawijaya Press.

Shatu, Yayah Pudin. 2016. Kuasa Detail Akuntansi Perkantoran. Medan : Pustaka Ilmu Semesta

Sutabri, Tata. 2012. Analisis Sistem Informasi. Yogyakarta : Penerbit Andi http://eprints.polsri.ac.id/5624/3/BAB\%20II\%20NoviaS.pdf Diakses pada 14 April 2020

http://eprints.perbanas.ac.id/4121/7/Artikel\%20Ilmiah.pdf Diakses pada 15 April 2020 https://repository.unej.ac.id/bitstream/handle/123456789/92282/Nila\%20Anindya\% 20Anggraini-160803102005.pdf?sequence $=1$ Diakses pada 18 April 2020

https://docplayer.info/59673965-Bab-2-landasan-teori-2-1-pelanggan-pengertianpelanggan-kepuasan-pelanggan.html Diakses pada 18 April 2020

https://www.seputarforex.com/artikel/peran-konsumen-dan-produsen-dalamperekonomian-63883-31 Diakses pada 18 April 2020 